\title{
Phytochemical and Biological Investigation of Bridelia tomentosa Blume Growing in Bangladesh
}

\section{Adeeba Anjum ${ }^{1,2}$, Md. Ruhul Kuddus ${ }^{1}$, Md. Zakir Sultan ${ }^{3}$, Abdullah Al Mansur ${ }^{4}$, Choudhury M. Hasan ${ }^{1}$ and Mohammad A. Rashid ${ }^{1}$}

\author{
${ }^{1}$ Phytochemical Research Laboratory, Department of Pharmaceutical Chemistry, Faculty of Pharmacy, \\ University of Dhaka, Dhaka-1000, Bangladesh \\ ${ }^{2}$ Department of Pharmacy, University of Rajshahi, Rajshahi-6205, Bangladesh \\ ${ }^{3}$ Centre for Advanced Research in Sciences (CARS), University of Dhaka, \\ Dhaka-1000, Bangladesh \\ ${ }^{4}$ Institute of National Analytical Research and Service (INARS), Bangladesh Council of Scientific and \\ Industrial Research (BCSIR), Dr. Kudrat-I-Khuda Road, Dhanmondi, Dhaka-1205, Bangladesh
}

(Received: September 19, 2021; Accepted: December 14, 2021; Published (web): December 26, 2021)

\begin{abstract}
Bridelia tomentosa Blume is a small evergreen tree which has enormous folklore applications in the treatment of colic, traumatic injury, epidemic influenza and neurasthenia. The main purpose of this study was to isolate bioactive compounds from the stem bark of B. tomentosa growing in Bangladesh. Extensive chromatographic separation and purification of the methanolic extract of stem bark of $B$. tomentosa led to the isolation of four compounds. The purified constituents were identified as friedoolean-5(6),14(15)-dien-3-one (1), $\beta$-taraxerol (2), $\mathrm{D}_{4^{-}}$ stigmasterone (3) and lupeol (4) by extensive analysis of NMR spectroscopic data. While compound $\mathbf{1}$ is appeared to be new, the other compounds (2-4) have been isolated for the first time from this plant. $\beta$-taraxerol (2) demonstrated significant cytotoxic activity against the brine shrimp Artemia salina and moderate to strong antimicrobial efficacy with the highest inhibitory potential against Salmonella Typhi (zone of inhibition $=21.3 \mathrm{~mm}$ ) and Sarcina lutea (zone of inhibition $=20.8 \mathrm{~mm}$ ). In conclusion, $B$. tomentosa has been found to be a rich source of secondary metabolites and thus it may be studied further in order to isolate of more bioactive constituents.
\end{abstract}

Key words: Bridelia tomentosa, Triterpenes, Steroids, Cytotoxicity, Antimicrobial

\section{INTRODUCTION}

Bridelia tomentosa Blume (Bengali name: Khy, Serai, Family: Phyllanthaceae) is a large tree found in the woodland areas of Sylhet, Srimangal and Chattogram as well as in Dinajpur in Bangladesh. The plant also grows in India, China, Philippines and Northern Australia. ${ }^{1}$ Leaves of this plant have beneficial effect for traumatic injury. Bark has astringent property and roots are used in influenza and neurasthenia. ${ }^{2}$ Previous phytochemical investigation of the fruits of $B$. tomentosa led to isolation of quercetin, tamarixetin, $\beta$-amyrin, ethylgallate, gallic acid, friedelin etc. Two flavonoid

Correspondence to: Mohammad A. Rashid

E-mail: r.pchem@yahoo.com

Dhaka Univ. J. Pharm. Sci. 20(2): 213-218, 2021 (December)

DOI: https://doi.org/10.3329/dujps.v20i2.57171 glycosides have been isolated from the leaves of $B$. tomentosa. ${ }^{3,4}$

Although there are several reports on the ethnopharmacological studies of Bridelia species, a few articles have been published regarding the phytochemical and biological investigations of $B$. tomentosa. Therefore, in continuation of our previous works on medicinal plants of Bangladesh ${ }^{5-7}$, including on Bridelia ${ }^{8,9}$ species, we have examined the methanol extract of stem bark of $B$. tomentosa for isolation and characterization of the secondary metabolites and subsequent evaluation of cytotoxic and antimicrobial properties of these pure compounds and we, here in, report the results of our investigation. 


\section{MATERIAL AND METHODS}

Plant materials. Stem bark of $B$. tomentosa was harvested from Khagrachari district of Bangladesh in February, 2007. The identity of the plant was confirmed in Bangladesh National Herbarium, Mirpur, Dhaka-1216, where a voucher specimen has been deposited with the accession number of DACB31377.

Extraction and preparation of plant extract. The powdered stem bark of $B$. tomentosa $(575 \mathrm{~g})$ was soaked in $1.5 \mathrm{~L}$ methanol for one week. Filtrations of the plant extract were done by using fresh cotton bed, and finally by Whatman No. 1 filter paper. The filtrate was concentrated with the help of a rotary evaporator at $40^{\circ} \mathrm{C}$ and at reduced pressure to yield a gummy mass.

Isolation of chemical constituents. For purification of chemical compounds, an aliquot (20 g) of the crude extract of $B$. tomentosa was subjected to VLC column (14 cm length and $10 \mathrm{~cm}$ in diameter) over silica gel $60 \mathrm{H}$. The sample from the VLC column was eluted with petroleum-ether, followed by mixtures of petroleum-ether and ethyl acetate in order of increasing polarities and lastly with methanol. After TLC screenings, the VLC fractions with identical TLC features were mixed together. VLC fractions labeled as $4 \mathrm{~A}$ and $4 \mathrm{~B}$; $5 \mathrm{~B}$ and $6 \mathrm{~A} ; 7 \mathrm{~B}$ and $8 \mathrm{~A}$; and $12 \mathrm{~A}, 12 \mathrm{~B}$ and $13 \mathrm{~A}$ being similar were combined separately. Preparative TLC of these mixtures using toluene and ethyl acetate provided compound $\mathbf{1}(8.04 \mathrm{mg})$ from fractions $4 \mathrm{~A}+4 \mathrm{~B}$, compound $2(5.11 \mathrm{mg})$ from fractions $5 \mathrm{~B}+6 \mathrm{~A}$, compound $3(6.29 \mathrm{mg})$ from fractions $7 \mathrm{~B}+8 \mathrm{~A}$ and compound $4(6.31 \mathrm{mg})$ from fractions $12 \mathrm{~A}+12 \mathrm{~B}+13 \mathrm{~A}$.

\section{Properties of isolated compounds (1-4)}

Friedoolean-5(6),14(15)-dien-3-one(1):

Colorless mass; ${ }^{1} \mathrm{H}$ NMR (400 MHz, $\left.\mathrm{CDCl}_{3}\right): \delta 5.68$ $(1 \mathrm{H}, \mathrm{m}, \mathrm{H}-6), 5.56(1 \mathrm{H}, \mathrm{dd}, J=8.2$ and $3.6 \mathrm{~Hz}, \mathrm{H}-$ 15), 1.23 (3H, s, Me-23), 1.22 (3H, s, Me-28), 1.16 (3H, s, Me-29), 1.08 (3H, s, Me-27), 1.02 (3H, s, Me-24), 0.98 (3H, s, Me-26), 0.95 (3H, s, Me-30), $0.81(3 \mathrm{H}, \mathrm{s}, \mathrm{Me}-25)$. $\beta$-taraxerol (2):Colorless gum; ${ }^{1} \mathrm{H}$ NMR (500 $\left.\mathrm{MHz}, \mathrm{CDCl}_{3}\right): \delta 5.52(1 \mathrm{H}, \mathrm{dd}, J=8.0$ and $3.5 \mathrm{~Hz}, \mathrm{H}-$ 15), $3.17(1 \mathrm{H}, \mathrm{dd}, J=10.05$ and $3.5 \mathrm{~Hz}, \mathrm{H}-3), 1.07$ (3H, s, Me-26), 0.96 (3H, s, Me-25), 0.93 (3H, s, Me30), 0.91 (3H, s, Me-29), 0.89 (3H, s, Me-24), 0.89 $(3 \mathrm{H}, \mathrm{s}, \mathrm{Me}-23), 0.80$ (3H, s, Me-27), 0.78 (3H, s, Me28).

$\mathrm{D}_{4}$-stigmasterone (3): White amorphous; ${ }^{1} \mathrm{H}$ NMR $\left(500 \mathrm{MHz}, \mathrm{CDCl}_{3}\right): \delta 5.76(1 \mathrm{H}, \mathrm{s}, \mathrm{H}-4), 5.13$ $(1 \mathrm{H}, \mathrm{dd}, J=15.1,8.3 \mathrm{~Hz}, \mathrm{H}-22), 5.01(1 \mathrm{H}, \mathrm{dd}, J=$ 15.0, $8.3 \mathrm{~Hz}, \mathrm{H}-23), 1.01$ (3H, s, Me-21), 0.89 (3H, d, $J=4.6 \mathrm{~Hz}, \mathrm{Me}-27), 0.85$ (3H, s, Me-19), 0.81 (3H, t, $J=6.6 \mathrm{~Hz}), 0.80(3 \mathrm{H}, \mathrm{d}, J=4.6 \mathrm{~Hz}, \mathrm{Me}-26), 0.71$ (3H, s, Me-18).

Lupeol (4): Crystalline powder; mp 215-216 ${ }^{\circ} \mathrm{C}$. ${ }^{1} \mathrm{H}$ NMR (500 MHz, $\left.\mathrm{CDCl}_{3}\right): \delta 4.68(1 \mathrm{H}, \mathrm{s}, \mathrm{H}-29 \mathrm{a})$, $4.56(1 \mathrm{H}, \mathrm{s}, \mathrm{H}-29 \mathrm{~b}), 3.22(1 \mathrm{H}, \mathrm{dd}, J=11.2,4.8 \mathrm{~Hz}$, H-3), 2.30 (1H, m, H-19), 1.67 (3H, s, Me-30), 1.02 (3H, s, Me-26), 0.96 (3H, s, Me-23), 0.94 (3H, s, Me27), 0.83 (3H, s, Me-25), 0.78 (3H, s, Me-24), 0.75 (3H, s, Me-28).

Cytotoxic activity. Brine shrimp lethality bioassay ${ }^{10,11}$ was employed to evaluate the cytotoxic potential of the test samples using vincristine sulfate (VS) and dimethyl sulfoxide (DMSO) as positive and negative control, respectively. The $\mathrm{LC}_{50}$ and $\mathrm{LC}_{90}$ of the test compounds were obtained by plotting the percentage of shrimp killed against the logarithm of the test sample concentration.

Antimicrobial activity. Antimicrobial activity of the test samples was determined by the disc diffusion method. ${ }^{12}$

\section{RESULTS AND DISCUSSION}

A total of four compounds, friedoolean5(6),14(15)-dien-3-one (1), $\beta$-taraxerol (2), $\quad \mathrm{D}_{4}$ stigmasterone (3) and lupeol (4) (Figure 1) were isolated from the methanolic extract of the stem bark of $B$. tomentosa by repeated chromatographic separation and purification over silica gel. The chemical structures of these compounds were elucidated by analysis of their NMR spectral data and comparison with published values. 
Compound 1 was characterized as friedoolean5(6),14(15)-dien-3-one by studying of its ${ }^{1} \mathrm{H}$ NMR data and comparison with those of related compounds. ${ }^{13-16}$ The ${ }^{1} \mathrm{H}$ NMR spectrum of compound 1 showed eight singlets each of three proton intensity at $\delta 0.81,0.95,0.98,1.02,1.08,1.16,1.22$ and 1.23 attributable to eight methyl groups present in the molecule. ${ }^{10}$ The spectrum further displayed two olefinic proton signals at $\delta 5.68(1 \mathrm{H}, \mathrm{m})$ and 5.56 $(1 \mathrm{H}, \mathrm{dd}, J=8.2$ and $3.6 \mathrm{~Hz})$ which could be assigned to $\mathrm{H}-6$ and $\mathrm{H}-15$, respectively of a pentacyclic

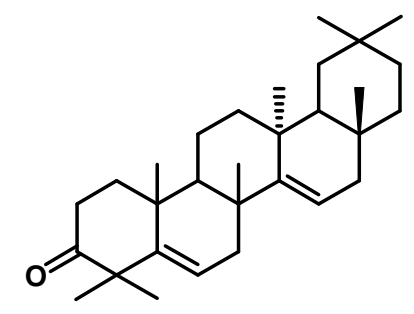

Friedoolean-5(6),14(15)-dien-3-one (1)

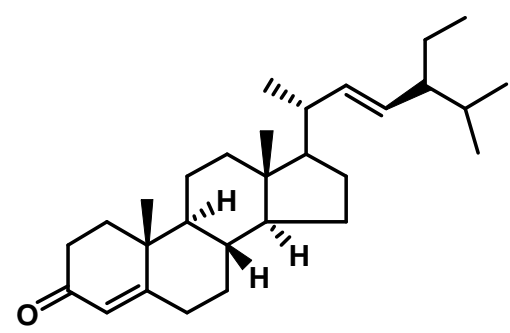

$\mathrm{D}_{4}$-stigmasterone (3) triterpenoid skeleton. ${ }^{13-15}$ Comparison of the ${ }^{1} \mathrm{H}$ NMR spectral data with reported values ${ }^{13-16}$ of related triterpenoids suggested the occurrence of a pentacyclic triterpenoid skeleton. Based on the above NMR data as well as by comparison with the chemical shifts of protons of structurally related triterpenes in the literatures ${ }^{13-16}$, compound $\mathbf{1}$ was tentatively characterized as friedoolean-5(6),14(15)dien-3-one. To the best of our knowledge, this study represents the first report of friedoolean-5(6),14(15)dien-3-one (1) from any nature and synthetic source.

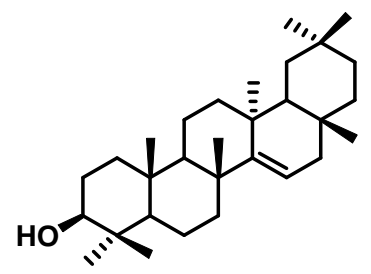

$\beta$-taraxerol (2)

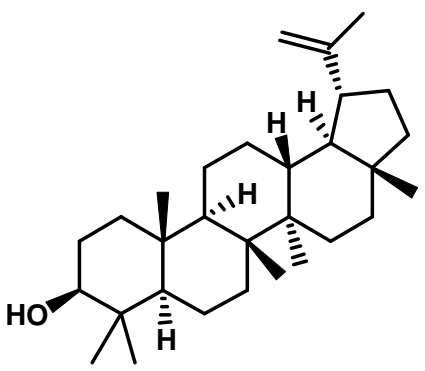

Lupeol (4)

Figure 1. Friedoolean-5(6),14(15)-dien-3-one (1), $\beta$-taraxerol (2), $\mathrm{D}_{4}$-stigmasterone (3) and lupeol (4) isolated from B. tomentosa.

The ${ }^{1} \mathrm{H}$ NMR spectrum of compound 2 showed eight three-proton singlets at $\delta 0.78,0.80,0.89,0.89$, $0.91,0.93,0.96$ and 1.07, which were assigned to the methyl group protons at Me-28, Me-27, Me-23, Me24, Me-29, Me-30, Me-25 and Me-27, respectively. The double doublet $(J=8.0,3.5 \mathrm{~Hz})$ of one proton intensity centered at $\delta 5.52$ was assigned to the olefinic proton at C-15. Another double doublet $(J=$ $10.5,3.5 \mathrm{~Hz}$ ) centered at $\delta 3.17$ could be assigned to the oxymethine proton at $\mathrm{C}-3$. The large couplings $(\mathrm{J}$ $=10.5,3.5 \mathrm{~Hz})$ of $\mathrm{H}-3$ with the vicinal methylene protons at C-2 demonstrated a beta orientation of the hydroxyl group at $\mathrm{C}-3$. The above information suggested the presence of a typical taraxaren-type pentacyclic triterpene skeleton and they were found to be in close agreement to those published for $\beta$ taraxerol. ${ }^{15}$ Therefore, the identity of compound 2 was confirmed as $\beta$-taraxerol.

The ${ }^{1}$ HNMR spectrum of compound $\mathbf{3}$ displayed resonances for six methyl groups, two of which were doublets at $\delta 0.80(\mathrm{~d}, J=4.6 \mathrm{~Hz})$ and $0.89(\mathrm{~d}, J=4.6$ $\mathrm{Hz}$ ), associated to an isopropyl group. Three 
resonances for methine protons were observed at $\delta$ 5.76 as a singlet, 5.13 as a double doublet (dd, $J=$ $15.1,8.3 \mathrm{~Hz}$ ) and 5.01 also as a double doublet (dd, $J$ $=15.0,8.3 \mathrm{~Hz}$ ). These were characteristics signals of $\mathrm{H}-4, \mathrm{H}-22$ and $\mathrm{H}-23$ in a $\mathrm{D}_{4}$-stigmasterone type carbon skeleton. Other spectral features were in close agreement to those of $\mathrm{D}_{4}$-stigmasterone. ${ }^{17}$ So, compound $\mathbf{3}$ was identified as $\mathrm{D}_{4}$-stigmasterone.

Compound 4 showed a ${ }^{1} \mathrm{H}$ NMR spectrum with a double doublet $(J=11.2,4.8 \mathrm{~Hz})$ at $\delta 3.22$, which is distinctive for an oxymethine proton at C-3 in a triterpene nucleus. The ${ }^{1} \mathrm{HNMR}$ spectral data of compound 4 were in close agreement with the published values for lupeol. ${ }^{18,19}$ Therefore, compound 4 was characterized as lupeol (Figure 1). The identity of compound $\mathbf{4}$ as lupeol was further confirmed by co-TLC with an authentic lupeol previously isolated in our laboratory.

However, this is the first report of isolation of $\beta$ taraxerol, $\mathrm{D}_{4}$-stigmasterone and lupeol from $B$. tomentosa.

Cytotoxicity of the test samples was performed by brine shrimp lethality bioassay. ${ }^{10,11}$ In this bioassay, a marine micro crustacean specimen, Artemia salina Leach (brine shrimp), was used as the target organism to detect cytotoxicity of plant extracts. As shown in Table 1 , the $\mathrm{LC}_{50}$ and $\mathrm{LC}_{90}$ values obtained from the best-fit line slope were found to be as $7.71 \mu \mathrm{g} / \mathrm{ml}$ and $99.31 \mu \mathrm{g} / \mathrm{ml}$, respectively for compound $\mathbf{2}$ isolated from $B$. tomentosa as compared to the $\mathrm{LC}_{50}$ for positive control (vincristine sulfate, $0.45 \mu \mathrm{g} / \mathrm{ml}$ ). Here, the percent mortality was found to increase gradually with the increase in concentration of the test sample. Brine shrimp lethality test is a very simple screening tool, which has a good correlation with the antitumor activity of test samples. ${ }^{10}$ The US National Cancer Institute (NCI, USA) established that, there is a significant correlation between the brine shrimp lethality and in vitro growth inhibition of human solid tumor cell lines. Thus, this bioassay is a very important pre-screening tool for antitumor drug research. ${ }^{20,21}$
The natural products from plant origin have more chemical scaffolds than that of the synthetic ones, which means they have appreciable benefits in supplying new leads in commercial drug discovery program. ${ }^{22}$ Hence, the main target or aim of our studies was to use the plant extract efficiently and effectively of this diversity. In recent times, the researchers have switched to plants for the search of prospective antimicrobial compounds. The multidrug resistant

Table 1. Effect of pure compound 2 isolated from the stem bark of $B$. tomentosa on brine shrimp nauplii.

\begin{tabular}{ccccc}
\hline $\begin{array}{c}\text { Conc. }(\mathrm{C}) \\
(\mu \mathrm{g} / \mathrm{ml})\end{array}$ & Log C & $\begin{array}{c}\% \\
\text { Mortality }\end{array}$ & $\begin{array}{c}\mathrm{LC}_{50} \\
(\mu \mathrm{g} / \mathrm{ml})\end{array}$ & $\begin{array}{c}\mathrm{LC}_{90} \\
(\mu \mathrm{g} / \mathrm{ml})\end{array}$ \\
\hline 400 & 2.602 & 100 & & \\
200 & 2.301 & 100 & & \\
100 & 2.000 & 90 & & \\
50 & 1.699 & 90 & & \\
25 & 1.398 & 80 & & \\
12.5 & 1.097 & 60.31 & & \\
6.25 & 0.797 & 50 & & \\
3.125 & 0.495 & 20 & & \\
1.563 & 0.194 & 30 & & \\
0.781 & -0.107 & 10 & & \\
\hline
\end{tabular}

Table 2. Results of the antimicrobial screening of the compound 2.

\begin{tabular}{lcc}
\hline Test organisms & \multicolumn{2}{c}{$\begin{array}{c}\text { Diameter of zone of inhibition } \\
(\mathrm{mm})\end{array}$} \\
\hline Gram positive bacteria & $\begin{array}{c}\text { Compound } 2 \\
(50 \mu \mathrm{g} / \mathrm{disc})\end{array}$ & $\begin{array}{c}\text { Kanamycin } \\
(30 \mu \mathrm{g} / \mathrm{disc})\end{array}$ \\
\hline Bacillus cereus & 19.1 & 35 \\
B. megaterium & 16.7 & 35 \\
B. subtilis & 14.9 & 36 \\
Staphylococcus aureus & 16.4 & 32 \\
Sarcina lutea & 20.8 & 27 \\
\hline Gram negative bacteria & & \\
\hline Escherichia coli & 19.1 & 25 \\
Pseudomonas aeruginosa & 16.9 & 22 \\
Salmonella Typhi & 21.3 & 27 \\
S. Paratyphi & 19.7 & 27 \\
Shigella boydii & 19.8 & 25 \\
S. dysenteriae & 19.6 & 25 \\
Vibrio mimicus & 17.2 & 20 \\
V. parahemolyticus & 18.4 & 19 \\
\hline Fungi & 15.8 & Griseofulvin \\
\hline Aspergillus niger & 12.7 & $(20 \mathrm{~g} / \mathrm{Disc})$ \\
Candida albicans & & 20 \\
Saccharomyces cerevisiae & & 18 \\
\hline
\end{tabular}


strains of the pathogens to the presently used antibiotics is another reason for the search of new antimicrobial agents. So, many medicinal plants have been extensively explored globally for their antimicrobial potential. ${ }^{23-26}$ In the present study, compound 2 produced zone of inhibition ranging from 14-21 mm (Table 2) at a concentration of 50 $\mu \mathrm{g} /$ disc. The maximum zone of inhibition $(21.3 \mathrm{~mm})$ was displayed by compound $\mathbf{2}$ against $S$. Typhi.

During antifungal screening, the zone of inhibition produced by the test sample, compound $\mathbf{2}$ was between 12.7-15.8 mm signifying moderate to strong activity compared to standard griseofulvin with the zone of inhibition $18-20 \mathrm{~mm}$. Compound 2 showed the uppermost antifungal property against $A$. niger $($ zone of inhibition $=15.8 \mathrm{~mm})$.

\section{CONCLUSION}

Chromatographic separation and purification of the stem bark extract of $B$. tomentosa afforded four compounds identified as friedoolean-5(6),14(15)dien-3-one (1), $\beta$-taraxerol (2), $\mathrm{D}_{4}$-stigmasterone (3) and lupeol (4), while compound $\mathbf{1}$ has been proposed as a new compound and compounds $\mathbf{2 - 4}$ are the first report of their isolation from $B$. tomentosa. Purified compound 2 showed moderate cytotoxicity against brine shrimp nauplii and strong antibacterial activity against a series of test microorganisms listed in Table 2. Since, B. tomentosa is rich source of secondary metabolites, this can be considered as a potential source of antimicrobial and cytotoxic agent in the development of new therapeutic molecules.

\section{ACKNOWLEDGEMENTS}

We are grateful to Dr. Bushra Khan, Senior Scientific Officer, Bangladesh National Herbarium for identification of the plant sample. We are also thankful to Biomedical Research Centre (BRC), University of Dhaka, and Department of Pharmacy, State University of Bangladesh (SUB), Dhaka-1205, Bangladesh for providing necessary laboratory facilities to carry out part of our research activities.

\section{REFERENCES}

1. Hooker, J.D. 1875. The Flora of British India, Vol. LV Reeve and Co., London, pp. 267-271.

2. Krishnan, K.S. 1992. The Useful Plants of India, Reprinted, Publications and Information Directorate, CSIR, New Delhi, India, pp. 86-87.

3. Hailin, Q. 2008. Studies on chemical constituents of fruits of Bridelia tomentosa. China J. Chinese Mat. Med. 33, 158-160.

4. Shu, S.H., Zhang, J.L., Wang Y.H. and Qin, H.L. 2006. Two new flavonol glycosides from Bridelia tomentosa. Chinese Chem. Lett. 17, 1339-1342.

5. Bulbul, I.J., Uddin, M.E., Nahar, N., Kuddus, M.R., Haque, M.R. and Rashid, M.A. 2021. Antidiarrheal activity of four different species ofLitsea available in Bangladesh. Biomed. Pharmacol. J. 14, 1259-1266.

6. Chowdhury, P., Shahadati, S., Ibrahim, M., Kuddus, M.R. and Rashid, M.A. 2021. In vitro and in vivo evaluation of pharmacological potentials of Lasia spinosa Linn. Dhaka Univ. J. Pharm. Sci. 20, 111-119.

7. Ahamed, M.H., Al Faruk, A., Ibrahim, M., Kuddus, M.R., Sikder, M.A.A. and Rashid, M.A. 2021. Exploration of phytochemical and pharmacological potentials of Canarium resiniferum Bruce ex King, an endangered medicinal plant of Bangladesh. Trop. J. Nat. Prod. Res. 5, 825-830.

8. Anjum, A., Haque, M.R., Rahman, M.S., Hasan, C.M., Haque, M.E. and Rashid, M.A. 2011. In vitro antibacterial, antifungal and cytotoxic activity of three Bangladeshi Bridelia species. Int. Res. Pharm. Pharmacol. 1, 149-154.

9. Anjum, A., Sikder, M.A., Haque, M.R., Hasan, C.M. and Rashid, M.A. 2013. In vitro antioxidant and thrombolytic activities of Bridelia species growing in Bangladesh. J. Sci. Res. 5, 343-351.

10. McLaughin, J.L., Rogers, L.L. and Anderson, J.E. 1998. The use of biological assays to evaluate botanicals. Drug Inf. J.32, 513-524.

11. Meyer, B.N., Ferringni, N.R., Putnam, J.E., Jacobsen, L.B., Nichols, D.E. and McLaughin, J.L. 1982. Brine shrimp: A convenient general bioassay for active plant constituents. Planta Med. 45, 31-32.

12. Bauer, A.W., Kirby, W.M., Sherries, J.C. and Turck, M. 1966. Antibiotic susceptibility testing by a standardized single disc method. Am. J. Clin. Pathol. 45, 493-496.

13. Xue-jing, L., Xie, Z., Wang, Y.H., Yan, Y.M., Pei, G. and Zhou, X.J. 2012. Study on the chemical constituents from the leaves of Hydnocarpus haimanensis. Zhong Yao Cai. 35, 1782-1784.

14. Shazid, M.S., Hossain, M.K., Haque, M.R., Chowdhury, A.A., Kaisar, M.A., Hasan, C.M. and Rashid, M.A. 2012. Chemical and biological studies of Kalanchoe pinnata (Lam.) growing in Bangladesh. Asian Pac. J. Trop. Biomed. S1317-S1322. 
15. Fakir, S.T., Sohrab, M.H., Chowhdury, A.M.S.U., Afroz, F., Al-Mansur, M. and Hasan, C.M. 2009. Phytochemical studies on the leaves of Xylia dolabriformis. Dhaka Univ. J. Pharm. Sci. 8, 171-172.

16. Moulisha, B., Bikash, M.N., Partha, P., Kumar, G.A., Sukdeb, B. and Kanti, H.P. 2009. In vitro anti-leishmanial and anti-tumour activities of a pentacyclic triterpenoid compound isolated from the fruits of Drega volubilis Benth. Asclepiadaceae. Trop. J. Pharm. Res. 8, 127-131.

17. Georges, P., Sylvestre, M., Ruegger, H. and Bourgeois, P. 2006. Ketosteroids and hydroxyketosteroids, minor metabolites of sugarcane wax. Steroids 71, 1016-1021.

18. Jahan, I., Rahman, M.S., Rahman, M.Z., Kaisar, M.A., Islam, M.S., Wahab, A. and Rashid, M.A.2010. Chemical and biological investigations of Delonix regia (Bojer ex Hook.). Acta Pharm. 60, 207-215.

19. Fahad, T.A., Kuddus, M.R. and Hasan, C.M. 2020. Phytochemical and biological studies of bark extract of Miliusa velutina (Dunal) Hook. f. \& Thomson. Dhaka Univ. J. Pharm. Sci.19, 125-131.

20. Anderson, J.E., Goetz, C.M., McLaughlin, J.L. and Suffness, M. 1991. A blind comparison of simple bench-top bioassay and human tumor cell cytotoxicities as antitumor prescreens. Phytochem. Anal. 2, 107-111.
21. Arcanjo, D.D.R., Albuquerque, A.C.M., Melo, N.B., Santana, L.C.L.R., Medeiros, M.G.F. and Cito A.M.G.L. 2012. Bioactivity evaluation against Artemia salina Leach of medicinal plants used in Brazilian Northeastern folk medicine. Braz. J. Biol. 72, 505-509.

22. Harvey, A. 2000. Strategies for discovering drugs from previously unexplored natural products. Drug Discov. 5, 294300.

23. Gaur, G.J. and Arora, D.S. 2009. Antibacterial and phytochemical screening of Anethum graveolens, Foeniculum vulgare and Trachyspermum ammi. BMC Complement Altern. Med. 9, 30.

24. Adedapo, A.A., Mogbojuri, O.M. and Emikpe, B.O. 2009. Safety evaluation of the aqueous extracts of the leaves of Moringa oleifera. J. Med. Plants Res. 3, 585-591.

25. Anjum, A., Sultan, M.Z., Hasan, C. M. and Rashid, M.A. 2017. Antibacterial and cytotoxic constituents from Bridelia verrucosa Haines growing in Bangladesh. Dhaka Univ. J. Pharm. Sci. 16, 61-68.

26. Anjum, A., Sultan, M.Z., Ferdosh, S., Islam, M.K., Rashid, M.A., Nahar, L., Sarker, S.D. 2021. Flavonoid, pterocarpans and steroid from Erythrina fusca Lour. growing in Bangladesh: isolation, and antimicrobial and free-radical scavenging activity. J. Med. Plants 20, 37-46. 